\title{
Hubungan antara Persentase Lemak Tubuh, Lingkar Perut, Lingkar Pinggang dan Kekuatan Otot Punggung pada Mahasiswa Olahraga
}

\author{
Bazzar Ari Mighra), "Wahyuningsih Djaali ${ }^{2)}$
}

Program Studi Ilmu Keolahragaan, Fakultas Ilmu Olahraga, Universitas Negeri Jakarta

Correspondence author: inchy86@yahoo.com

Received : 4 April $2021 \quad$ Accepted : 30 September 2021

Published: 30 September 2021

DOI: https://doi.org/10.37012/jik.v13i2.527

\begin{abstract}
ABSTRAK
Komposisi lemak tubuh dipakai sebagai salah satu komponen yang berhubungan dengan kebugaran jasmani yang berhubungan dengan kesehatan. Cukup banyak cara pemeriksaan komposisi tubuh yang dapat dilakukan, antara lain pemeriksaan indeks massa tubuh (IMT), Skinfold Caliper, dan Bioelectrical Impedance Analysis (BIA). Tujuan penelitian ini adalah untuk mengetahui bagaimana hubungan persentase lemak tubuh, lingkar perut, lingkar pinggang dan kekuatan otot punggung pada mahasiswa olahraga. Penelitan dilakukan pada 30 mahasiswa olahraga FIK UNJ, dengan desain penelitian analitik obervasional. Dilakukan pengukuran IMT, persentase lemak tubuh menggunakan BIA, lingkar perut, lingkar pinggang, dan kekuatan otot punggung menggunakan "back and leg dynamometer". Hasil penelitian ini persentase lemak berkorelasi positif secara signifikan dengan lingkar perut (koefisien korelasi $r=0,598$ dan $p<0,001$ ), persentase lemak berkorelasi positif secara signifikan dengan lingkar pinggang (koefisien korelasi $r=0,616$ dan $\mathrm{p}<0,001$ ), dan persentase lemak tidak berkorelasi dengan kekuatan otot punggung (koefisien korelasi $r=0,204$ dan $p=0,279$ ).

Terdapat hubungan positif antara persentase lemak tubuh dengan lingkar perut, dan antara persentase lemak tubuh dengan lingkar pinggang, namun tidak terdapat hubungan yang signifikan antara persentase lemak tubuh dengan kekuatan otot punggung pada mahasiswa olahraga FIK UNJ.
\end{abstract}

Kata Kunci: Persentase Lemak Tubuh, Lingkar Perut, Lingkar Pinggang, Kekuatan Otot Punggung.

\begin{abstract}
Body fat composition is used as one of the components related to physical fitness related to health. There are many ways to check body composition, including body mass index (BMI), Skinfold Caliper, and Bioelectrical Impedance Analysis (BIA). The purpose of this study was to determine the relationship between body fat percentage, abdominal circumference, waist circumference and back muscle strength in sports students. The research was conducted on 30 sports students from FIK UNJ, with an observational analytic research design. Measurement of BMI, body fat percentage using BIA, abdominal circumference, waist circumference, and back muscle strength using a "back and leg dynamometer" were carried out. The percentage of fat was significantly positively correlated with abdominal circumference (correlation coefficient $r=0.598$ and $p<0.001$ ), the percentage of fat was significantly positively correlated with waist circumference (correlation coefficient $r=0.616$ and $p<0.001$ ), and the percentage of fat was not correlated with back muscle strength (correlation coefficient $r=0.204$ and $p=0.279$ ). There is a positive relationship between body fat percentage and abdominal circumference, and between body fat percentage and waist circumference, but there is no significant relationship between body fat percentage and back muscle strength in FIK UNJ sports students.
\end{abstract}

Keywords: Body fat percentage, abdominal circumference, waist circumference, back muscle strength. 


\section{PENDAHULUAN}

Lemak tubuh merupakan salah satu komponen tubuh yang menjadi perhatian karena berhubungan dengan kesehatan dan penurunan fungsional otot apabila berlebih, terutama pada seseorang dengan obesitas.(Tomlinson, Erskine, Morse, Winwood, \& OnambéléPearson, 2016) Komposisi lemak tubuh dipakai sebagai salah satu komponen yang berhubungan dengan kebugaran jasmani yang berhubungan dengan kesehatan. Seseorang yang memiliki lemak tubuh lebih banyak dikatakan memiliki kebugaran atau kemampuan yang lebih kecil dalam menghasilkan energi, karena jaringan yang tidak aktif juga lebih banyak.(Afriwardi (2010). Ilmu Kedokteran Olahraga. Jakarta : EGC.)

Cukup banyak cara pemeriksaan komposisi tubuh yang dapat dilakukan. Salah satu yang paling umum dilakukan adalah pemeriksaan indeks massa tubuh (IMT) yang mencakup pengukuran berat badan dan tinggi badan. Pengukuran lain dilakukan pada subkutan di lokasi tertentu pada lipatan kulit, antara lain dengan Skinfold Caliper, namun karena pemeriksaan ini sangat bergantung pada ketrampilan dan ketelitian pengukur menyebabkan hasilnya dapat bervariasi. Terdapat pemeriksaan analisis komposisi tubuh yang aman, mudah, tidak invasive, akurat, murah dan tidak mengganggu privasi, yaitu dengan pemeriksaan Bioelectrical Impedance Analysis (BIA).(Wijayanti, Sukmaningtyas, \& Fitranti, 2018)

Pemeriksaan kekuatan otot punggung merupakan salah satu tes yang umum dilakukan pada atlet. Kekuatan otot punggung yang baik bermanfaat dalam pencegahan sakit punggung, memperbaiki postur punggung, dan meningkatkan keseimbangan.(Adiatmika \& Santika, 2016; Santika, 2017) Kekuatan otot salah satunya dipengaruhi oleh latihan olahraga, sehingga seseorang yang rutin melakukan latihan umumnya memiliki kekuatan otot yang baik.(Setiowati, 2014) Pada penelitian ini ingin diketahui bagaimana hubungan antara komposisi tubuh dalam hal ini persentase lemak, lingkar perut dan lingkar pinggang, dengan kekuatan otot punggung. Tujuan penelitian ini adalah untuk mengetahui bagaimana hubungan persentase lemak tubuh, lingkar perut, lingkar pinggang dan kekuatan otot punggung pada mahasiswa olahraga.

\section{METODE}

Penelitian dilakukan di Fakultas Ilmu Keolahragaan Universitas Negeri Jakarta (FIK UNJ) pada bulan Agustus 2021, dengan tetap menerapkan protokol kesehatan karena penelitian dilakukan di masa pandemi. Desain penelitian yang dilakukan adalah penelitian analitik obervasional dengan teknik pengambilan sampel "purposive sampling" pada atlet futsal 
mahasiswa olahraga FIK UNJ. Total jumlah sampel yang mengikuti penelitian adalah 30 orang. Tahapan pengumpulan sampel yaitu dengan meminta persetujuan (informed consent) untuk ikut dalam penelitian. Dilakukan pengukuran berat badan (BB), tinggi badan (TB), indeks massa tubuh (IMT), persentase lemak tubuh, lingkar perut, lingkar pinggang, dan kekuatan otot punggung. Persentase lemak tubuh diukur dengan menggunakan alat Bioelectrical Impedance Analysis (merk Omron), dan kekuatan otot punggung diukur dengan menggunakan "back and leg dynamometer". Analisis data dilakukan dengan menggunakan SPSS. Dilakukan penghitungan rerata dan standar deviasi, dan nilai median dan rentang nilai pada masing-masing variabel yang diukur. Pengujian statistik dilakukan menggunakan uji korelasi sederhana pada variabel-variabel yang ingin dilihat korelasinya, dengan kemaknaan hasil uji dinilai dengan nilai $\mathrm{p}<0,05$, dan kekuatan korelasi dinilai dengan nilai $\mathrm{r}$.

\section{HASIL DAN PEMBAHASAN}

Karakteristik dasar subjek penelitian ditunjukkan pada tabel di bawah berdasarkan beberapa variabel, yaitu umur, berat badan, tinggi badan, indeks massa tubuh (IMT) dari 30 subjek penelitian. Deskripsi data disajikan dalam bentuk tabel yang berisi statistik rata-rata (mean), standar deviasi (SD), nilai minimum dan nilai maksimum.

Tabel 1.

Karakteristik demografi subjek penelitian

\begin{tabular}{lcccc}
\hline Karakteristik & Rerata & SD & Min & Maks \\
\hline Umur (tahun) & 18,37 & 0,89 & 17 & 20 \\
Berat badan $(\mathrm{kg})$ & 60,12 & 9,67 & 45 & 88 \\
Tinggi badan $(\mathrm{cm})$ & 168,67 & 5,73 & 158 & 185 \\
IMT $\left(\mathrm{kg} / \mathrm{m}^{2}\right)$ & 20,09 & 0,92 & 15,04 & 29,40 \\
\hline
\end{tabular}

Pada tabel 1 terlihat variabel umur, berat badan, tinggi badan dan indeks massa tubuh subjek penelitian. Untuk rata-rata umur sampel yang mengikuti penelitian adalah 18,37 tahun. Sampel yang mengikuti penelitian memiliki rerata berat badan $60,12 \mathrm{~kg}$ dan rerata tinggi badan 168,67 cm, dengan IMT rata-rata $20,09 \mathrm{~kg} / \mathrm{m}^{2}$. Berdasarkan hasil tersebut, maka mahasiswa olahraga yang ikut dalam penelitian ini tergolong tergolong pada kategori BMI normal. 
Tabel 2.

Hasil uji normalitas variabel persentase lemak, lingkar perut, lingkar pinggang dan kekuatan otot

\begin{tabular}{lccc}
\hline \multicolumn{1}{c}{ Karakteristik } & Rerata \pm SD & $\begin{array}{c}\text { Median } \\
(\text { min-maks })\end{array}$ & Nilai p \\
\hline Persentase Lemak $(\%)$ & $16,55 \pm 3,74$ & $16,4(10,8-25,9)$ & $0,200^{*}$ \\
Lingkar Perut $(\mathrm{cm})$ & $75,70 \pm 8,35$ & $74(64-102)$ & $0,033^{*}$ \\
Lingkar Pinggang $(\mathrm{cm})$ & $79,32 \pm 6,72$ & $79(66-98)$ & $0,200^{*}$ \\
Kekuatan Otot Punggung $(\mathrm{kg})$ & $30 \pm 20,23$ & $60(30-94)$ & $0,099 *$ \\
$*$ Uji Kolmogorov-Smirnov & & &
\end{tabular}

Dari tabel 2 dapat dilihat rerata persentase lemak pada subjek penelitian adalah 16,55 $\pm 3,74 \%$, sehingga dapat dikatakan bahwa persentase lemak pada mahasiswa olahraga yang ikut dalam penelitian ini tergolong normal. Hasil ini sesuai dengan kondisi normal rata-rata jumlah lemak tubuh orang dewasa berkisar antara $10-25 \%$ pada pria dan $18-30 \%$ pada wanita.(Amelia \& Syauqi, 2014)

Dari hasil uji statistik Kolmogorov-Smirnov untuk menilai distribusi data, terlihat bahwa pada variabel persentase lemak, lingkar pinggang dan kekuatan otot punggung datanya berdistribusi normal, sedangkan pada variabel lingkar perut, data tidak berdistribusi normal.

\section{Hubungan antara persentase lemak dengan lingkar perut}

Berdasarkan hasil uji analisis korelasi sederhana (korelasi Spearman), didapatkan bahwa persentase lemak berkorelasi positif secara signifikan dengan lingkar perut, dengan koefisien korelasi sebesar $r=0,598$ dan $\mathrm{p}<0,001$. Hal ini menunjukkan adanya hubungan positif antara persentase lemak dengan lingkar perut.

Lingkar perut yang berlebih berhubungan dengan berlebihnya lemak tubuh dan obesitas. Obesitas dikaitkan dengan keterbatasan fungsional dalam kinerja otot termasuk keterbatasan mobilitas, kekuatan dan postural. Sehingga pada seseorang dengan lingkar perut berlebih, secara teori dapat mempengaruhi penurunan kekuatan otot punggung.(Tomlinson et al., 2016)

\section{Hubungan antara persentase lemak dengan lingkar pinggang}

Berdasarkan hasil uji analisis korelasi sederhana (korelasi Pearson), didapatkan bahwa persentase lemak berkorelasi positif secara signifikan dengan lingkar pinggang, dengan koefisien korelasi sebesar $\mathrm{r}=0,616$ dan $\mathrm{p}<0,001$. Hal ini menunjukkan adanya hubungan positif antara persentase lemak dengan lingkar pinggang.

\section{Hubungan antara persentase lemak dengan kekuatan otot punggung}

Berdasarkan hasil uji analisis korelasi sederhana (korelasi Pearson), didapatkan bahwa persentase lemak tidak berkorelasi dengan kekuatan otot punggung (koefisien korelasi $\mathrm{r}=$ 
0,204 dan $\mathrm{p}=0,279$ ). Hal ini menunjukkan bahwa tidak adanya hubungan antara persentase lemak dengan kekuatan otot punggung. Hasil ini tidak sejalan dengan studi yang dilakukan oleh Setiowati (2014) mengenai persentase lemak tubuh,(Susilawati, Primayanti, \& Yundarwati, 2019) yang menyimpulkan bahwa terdapat hubungan antara persentase lemak tubuh dengan kekuatan otot.

\section{SIMPULAN DAN REKOMENDASI}

Kesimpulan yang dapat diambil dari penelitian ini adalah terdapat hubungan positif antara persentase lemak tubuh dengan lingkar perut, dan antara persentase lemak tubuh dengan lingkar pinggang. Selain itu tidak terdapat hubungan yang signifikan antara persentase lemak tubuh dengan kekuatan otot punggung pada mahasiswa olahraga Fakultas Ilmu Keolahragaan Universitas Negeri Jakarta.

\section{REFERENSI}

1. Adiatmika, I. P. G., \& Santika, I. G. P. N. A. (2016). Tes dan Pengukuran Olahraga. Denpasar, Bali, Indonesia: Udayana University Press.

2. Afriwardi (2010). Ilmu Kedokteran Olahraga. Jakarta : EGC.

3. Amelia, I. N., \& Syauqi, A. (2014). Hubungan antara asupan energi dan aktivitas fisik dengan persen lemak tubuh pada wanita peserta senam aerobik. Diponegoro University,

4. Santika, I. G. P. N. A. (2017). Pengukuran Komponen Biomotorik Mahasiswa Putra Semester V Kelas A Fakultas Pendidikan Olahraga Dan Kesehatan Ikip Pgri Bali Tahun 2017. Jurnal Pendidikan Kesehatan Rekreasi, 3(1), 85-92.

5. Setiowati, A. (2014). Hubungan indeks massa tubuh, persen lemak tubuh, asupan zat gizi dengan kekuatan otot. Media Ilmu Keolahragaan Indonesia, 4(1).

6. Susilawati, I., Primayanti, I., \& Yundarwati, S. (2019). Pengaruh Latihan Penguatan Otot Punggung (Back Exercise) Untuk Mencegah Nyeri Punggung (Back Pain) Pada Dosen Dan Karyawan Ikip Mataram. JISIP (Jurnal Ilmu Sosial dan Pendidikan), 3(1).

7. Tomlinson, D., Erskine, R., Morse, C., Winwood, K., \& Onambélé-Pearson, G. (2016). The impact of obesity on skeletal muscle strength and structure through adolescence to old age. Biogerontology, 17(3), 467-483.

8. Wijayanti, D. N., Sukmaningtyas, H., \& Fitranti, D. Y. (2018). Kesesuaian Metode Pengukuran Persentase Lemak Tubuh Skinfold Caliper Dengan Metode Bioelectrical Impedance Analysis. Faculty of Medicine. 